\title{
Foundation resistance analysis of Cisomang Bridge
}

\author{
Kaisha Tamara ${ }^{1, *}$ and Tommy Ilyas $^{2}$ \\ ${ }^{1}$ Department of Civil Engineering, Faculty of Engineering, Universitas Indonesia, Depok, Indonesia
}

\begin{abstract}
Cisomang bridge is one of the bridges connecting Jakarta and Bandung through Cikampek-Padalarang (Cipularang) Highway. The Road and Bridge's Research and Development Centre (PUSJATAN) presents data that on December 23rd, 2016 Pier P2 of Cipularang Highway is shifted for $57,02 \mathrm{~cm}$. This movement is suspected occurred due to decreasing of clayshale's shear strength caused by Cisomang River's seepage. Pier P2 movement is indicating lateral displacement of Cisomang Bridges foundation for $22 \mathrm{~m}$ deep which dominates the total displacement when compared to its settlement. Accordingly, we study trough back analysis method for determining the impact of bore pile reinforcement to lateral displacement on clayshale using PLAXIS to simulate the behaviour of soil. This research proposes $35 \mathrm{~m}$ and $60 \mathrm{~m}$ depth bore pile to be a foundation reinforcement. Aside from its contribution on decreasing lateral displacement of existing foundation up to $33-68 \%$, this reinforcement cuts the slip surface of Cipularang slope and increases its safety factor (SF) for 4,7-16\%.
\end{abstract}

\section{Introduction}

Foundation behaviour in a structure can be affected by few factors. One of them is changes of shear stress on soil which can cause lateral soil movement. This movement might increase the lateral load detained by a foundation [1]. This case study is taking place at Cipularang Highway in which topography has lots of steep slope. Other than that, these slopes are standing above clayshale layer with more than $60 \mathrm{~m}$ thickness. Clayshale is a soil with a severe possibility of changes on its material property when exposed to weather. This might happen because clayshale consist of clay minerals which dominated with Montmorilonite.

According to [2], clayshale is defined as black cotton soils which tends to flake as it is one of residual soil type. Thus, diagenetic bond of clay is lessened. When this condition reached, clay will tend to swell, increasing its water content, then decreasing its shear strength. On this case, Cisomang River's seepage might be the most possible cause of this broken diagenetic bond on Cisomang's clayshale. Monitoring data on December 2016 showed that Pier P2 on Cisomang Bridge shifted for $57,02 \mathrm{~cm}$. as Figure 1 showed, Pier P2 is located near Cisomang River and directly interacted with clayshale below.

Moreover, fine grained soil movement like clayshale will lead to slope stability problem such as slope failure. As soil reinforcement, bore pile will increase soil stiffness, control displacement, and provide lateral stability. Hence this study will determine impact of bore pile as a reinforcement to lateral displacement and slope stability on clayshale.

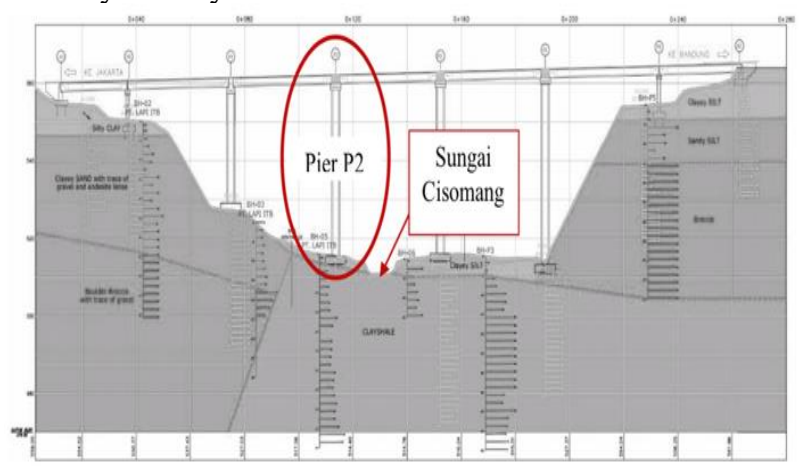

Fig. 1. Topography of Cisomang Bridge

\section{Research methodology}

This research is conducted using secondary data such as soil stratification based on N-SPT data, slope geometry based on contour map, and structural load based on bridge's structural analysis. The model is made half span from abutment A1 to pier P2 where the most lateral displacement occurs. We use plane strain model in PLAXIS to simulate soil behaviour. Mohr Coloumb model is used for every soil with variation especially on clayshale as summed in Table 1.

Table 1. Variation of clayshale based on NSPT.

\begin{tabular}{|c|c|}
\hline Clayshale Variation & N-SPT \\
\hline Highly Weathered & $8-22$ \\
\hline
\end{tabular}

\footnotetext{
* Corresponding author: kaishatamara@gmail.com
} 


\begin{tabular}{|c|c|}
\hline Weathered & $22-38$ \\
\hline Low Weathered & $40-50$ \\
\hline Not Weathered & $50-80$ \\
\hline
\end{tabular}

Based on correlation from N-SPT data, we decided to simplified soil stratification into clayshale, silty clay, clayey sand, and breccia summed in Table 2. Each soil property is decided through correlation from many literatures. Especially [3] research about Cisomang clayshale property including correlation between NSPT and its shear strength, a book written by [4], [5] research, and standard [6] related to breccia's property. The rest of soil parameters is interpreted using N-SPT value with tables and graphs in books written by $[2,7,8]$. These parameters tabulated in Table 2 (see Appendix) then validated to monitoring data at pier P1 and P2's pile cap which shifted. Ground water level is defined using piezometer reading data monitored until April 2017.

The scenario started with existing geometry model with existing bridge foundation and factored structural load from the bridge. Bore pile with a diameter of $1 \mathrm{~m}$ and a length of $22 \mathrm{~m}$ is modelled using plate and interface. Pile stiffness is defined through flexural and axial stiffness. Rinter value decided to be 0,8 based on [9] to define interaction between soft soil and concrete which is not rigid. Figure 2 shows the existing geometry model where pile cap is also modelled using plate and structural load is modelled using point load at the centre of each pile cap. In addition, total fixities defined at the outer side of slope geometry. Other than that, additional fixities defined at the top of bedrock soil which classified based on NSPT data. The geometry of this additional fixities modelled following the weathered clayshale layer depth because this model is validated with actual inclinometer data by December 2016 [10] which present 57,02 cm horizontal displacement. This research observes one specific pile in the middle of pier $\mathrm{P} 2$ as a reference point then comparing lateral displacement at pier $\mathrm{P} 2$ pile cap post improved.

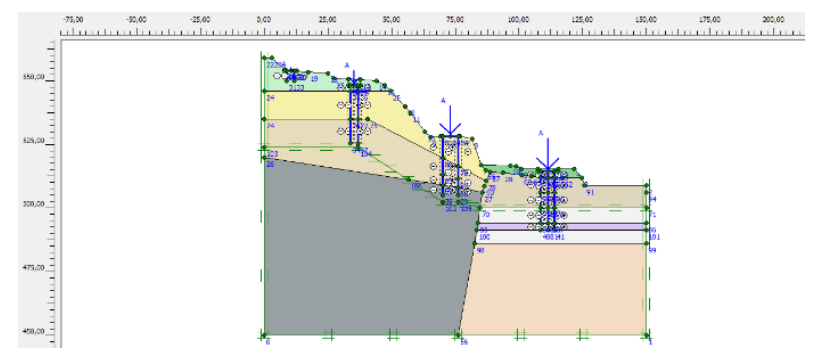

Fig. 2. Existing model

Fine mesh is used in this model with fine density to discretize geometry for separated calculation. Then, pore pressure is generated along with initial pressure. Because $\mathrm{K} 0$ concept is used in this research, total initial pressure is zero then gravity loading is generated on the first calculation. Next, the model calculated trough NIL-STEP phase which defined a condition in which no additional load applied to accommodate imbalance load after massive loading such as gravity loading phase. The next calculation phase is excavation, bore pile installation, pile cap installation, and structural loading. Delete intermediate step and reset displacement option is applied on pile cap installation phase to defined zero condition or no displacement occurs during construction phase.

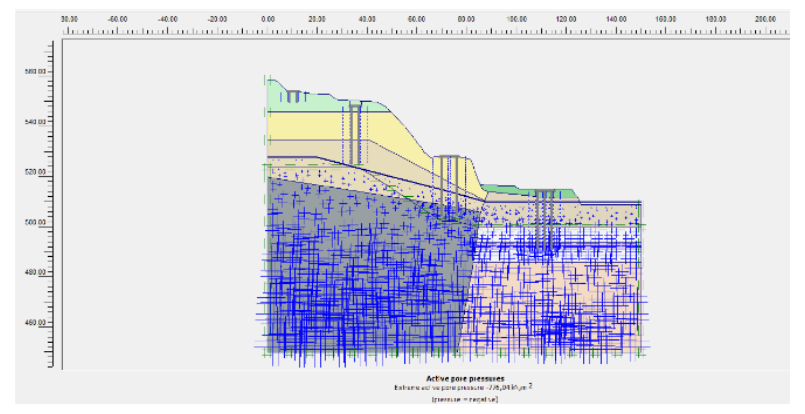

Fig. 3. Pore pressure generation based on GWL

Lateral displacement is analysed using plastic analysis from gravity loading phase through structural loading phase while slope stability is analysed using phi-c reduction analysis. Phi-c analysis is using soil $\tan \varphi$ and $\mathrm{c}$ which reduced gradually until failure. When interface defined, soil stiffness will gradually reduce. Incremental multiplier option is applied at slope stability analysis then Sum Msf can be obtained when failure occurs. Sum Msf value then represent slope's safety factor. Slip surface can also be obtained when phi-c reduction is done.

This research proposed bore pile with a $1,5 \mathrm{~m}$ diameter as soil reinforcement with two length variation which is $35 \mathrm{~m}$ and $60 \mathrm{~m}$. This depth is decided $5 \mathrm{~m}$ below the not weathered clayshale and in the middle of the not weathered clayshale layer to obtain the impact of depth to lateral displacement.

\section{Result and discussion}

In numerical analysis, critical slip surface can be obtained by examining contour of total displacement. Figure 4 illustrate contour of total displacement occurs at failure. Slip surface of existing slope used in validation for soil parameter is convergent with monitoring data whether in amount or vector. This model shows pier P1 shifted for 26 $\mathrm{cm}$ while pier P2 shifted for $57,13 \mathrm{~cm}$. Deep seated slip surface occurs with 1,389 as safety factor at this slope from pier P0 pushing to pier P2. In order to optimize soil reinforcement design, bore pile varied in amount, length, and location. Bore pile reinforcement located in the most critical location around pier P2. Those location are $4 \mathrm{~m}$ at the right side, $8 \mathrm{~m}$ at the left side, and both side of pier P2. As mentioned before, the length varied for $35 \mathrm{~m}$ and 60 $\mathrm{m}$, also used to cut slip surface in order to increase slope stability in amount of safety factor.

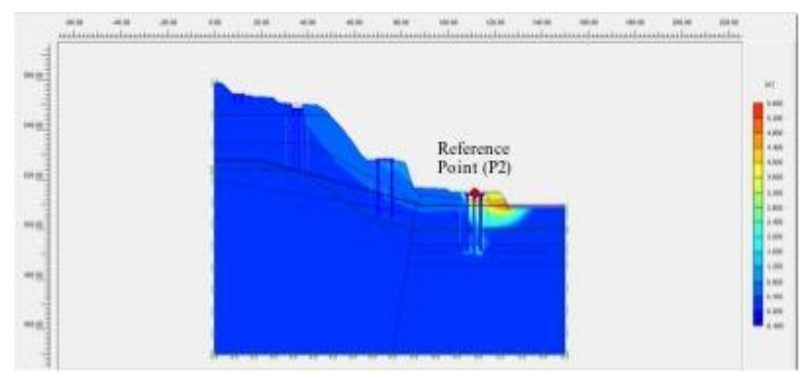

Fig. 4. Slip surface of existing slope and reference point 
Limited by slope geometry, the amount of pier located at the right side of pier P2 cannot be more than one. Thus, variation of pier amount exists at the left side of pier P2 from one to three rows as illustrated with an overview sketch in Figure 5.

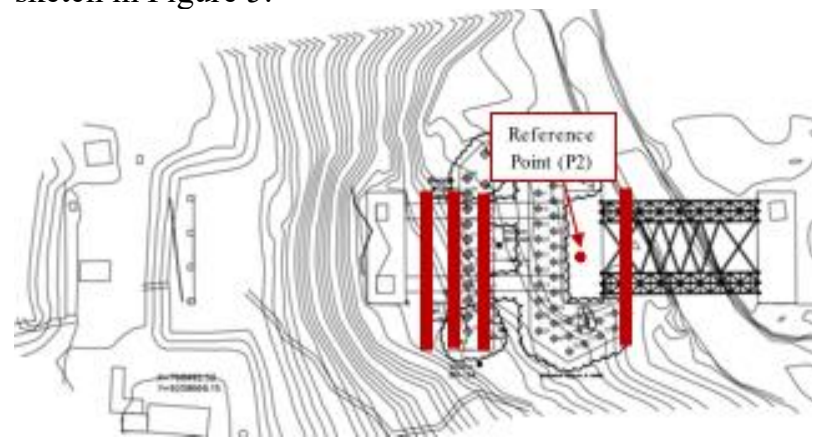

Fig. 5. Bore pile reinforcement variation (red lines)

\subsection{Right side of pier P2}

Figure 6 shows that soil vector is dominated by lateral displacement on both models. Lengthen bore pile reinforcement from $35 \mathrm{~m}$ to $60 \mathrm{~m}$ is insignificant because it increases lateral displacement for $0,2 \mathrm{~mm}$ with the most shift is for $22,57 \mathrm{~cm}$ at pile head of the existing pile on pier P2. When lateral displacement observed few depths, this research obtain that bore pile decreases lateral displacement better at half-length to the bottom of the existing pile.

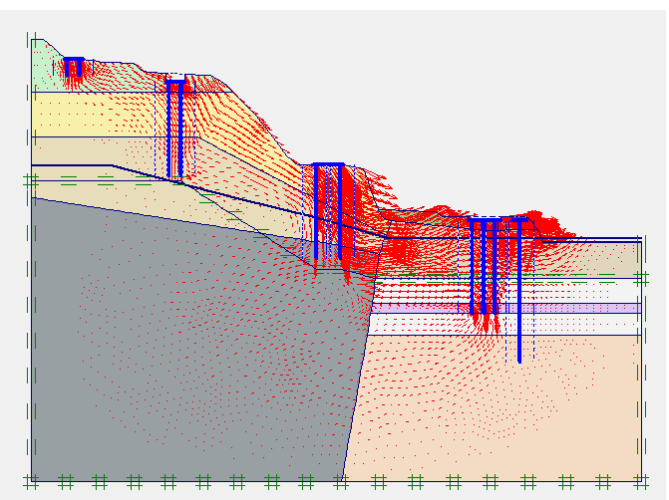

(a)

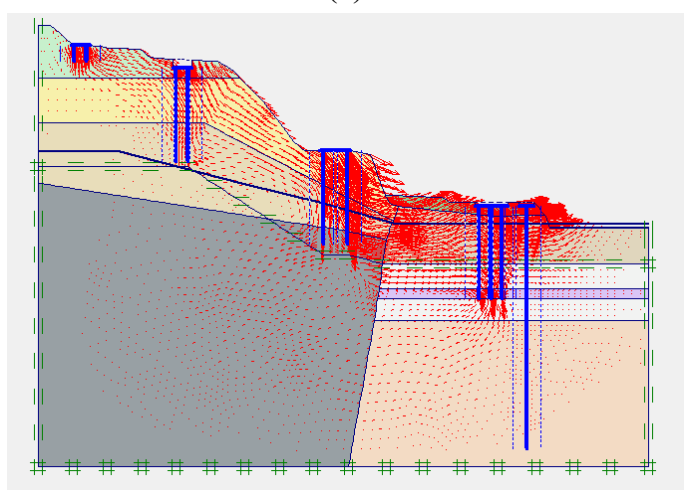

(b)

Fig. 6. Total displacement post-reinforced at the right side of pier P2 (a) $35 \mathrm{~m}$, (b) $60 \mathrm{~m}$.
Slope stability analysis obtained that critical slip surface moved into the left side of pier P2. After the reinforcement was applied, safety factor increases 4,7$5,6 \%$ varies with reinforcement bore pile length.

\subsection{Left side of pier P2}

Lateral displacement on pier P1 pile cap decreased about $16 \%$ after this reinforcement applied. On the other hand, pile head on pier P2 (reference point on Figure 4) shifted for $38,04 \mathrm{~cm}$ and soil vector is still dominated by lateral displacement on both models. The pattern of displacement occurs after bore pile reinforcement applied is still massive from pile head to half-length of the existing pile. But the amount of lateral displacement half-length to bottom of the existing pile is less than the previous reinforcement which is near zero. This phenomenon can be seen in Figure 7 where soil vector is dominated at the top of soil layer.

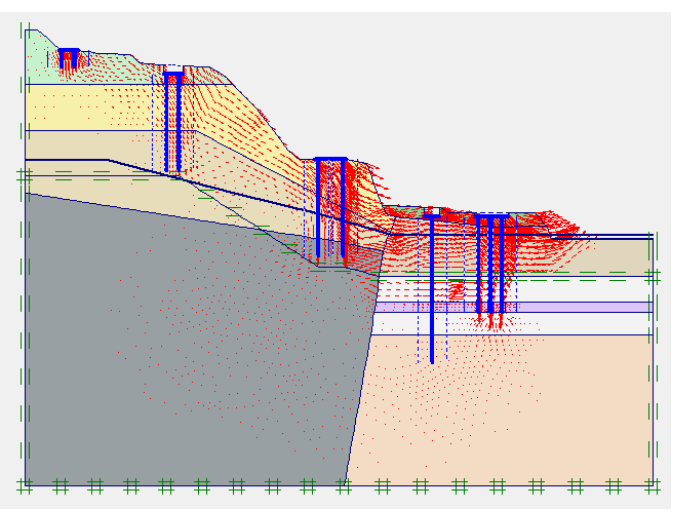

(a)

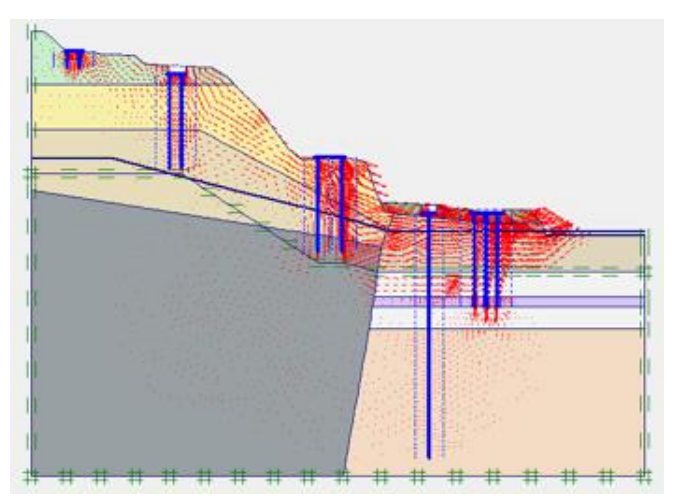

(b)

Fig. 7. Total displacement post-reinforced at the left side of pier P2 (a) $35 \mathrm{~m}$, (b) $60 \mathrm{~m}$.

As the reinforcement is located on the left side of pier P2, slope stability analysis obtained that critical slip surface is getting deepen on the right side of pier P2. The cut slip surface thus increases safety factor for 5,3-6,9 $\%$ varies with bore pile reinforcement length compared to the existing. 


\subsection{Both side of pier P2}

To optimize both advantages from the previous reinforcement, this research adds bore pile reinforcement at both right and left side of pier P2. Lateral displacement at reference point's pile head decreases up to $65 \%$ from $57 \mathrm{~cm}$ to $20,28 \mathrm{~cm}$ when the length of bore pile reinforcement is $35 \mathrm{~m}$. Increasing length into $60 \mathrm{~m}$ only decreasing another $1 \mathrm{~mm}$ at reference point's pile head, thus it is also insignificant to lengthen reinforcement pile. At half-length of reference point's pile, lateral displacement occurs at about $8 \mathrm{~cm}$. Meanwhile only $1 \mathrm{~cm}$ lateral displacement occurs at the bottom pile of reference point's pile. This explains the same behaviour in which bore pile decrease lateral displacement better half-length to bottom of the existing pile.

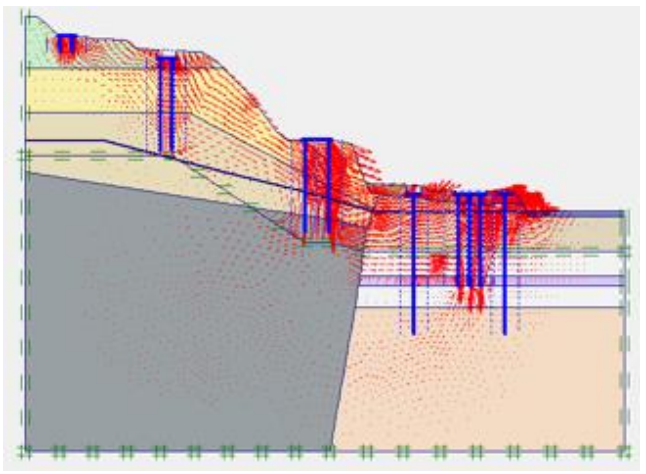

(a)

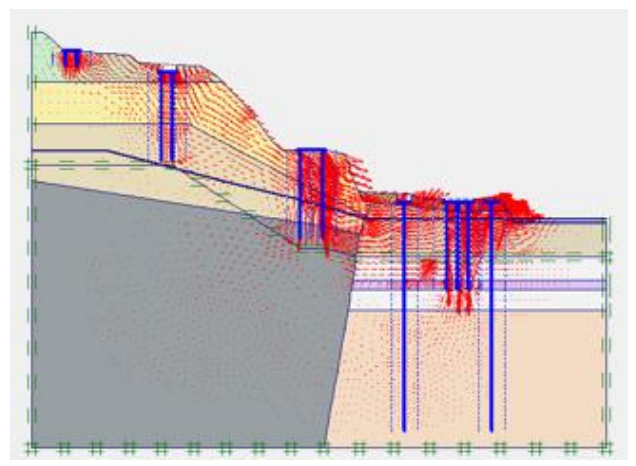

(b)

Fig. 8. Total displacement post-reinforced at both side of pier P2 (a) $35 \mathrm{~m}$, (b) $60 \mathrm{~m}$.

Slope stability analysis obtained that critical slip surface moved into the left side of pier P2. This happens because lateral soil movement from crest of the slope shifts the soil below and affect clayshale which already has low shear strength. After the reinforcement was applied, lateral soil movement is restrained. Then safety factor increases for $10-11,8 \%$ varies with reinforcement pile length.

\section{41 Row at right side and 2 rows at left side of pier P2}

Figure 9 presents that less lateral displacement obtained by adding rows of reinforcement pile. Lateral displacement at reference point's pile head decreases up to $19,28 \mathrm{~cm}$. Increasing length into $60 \mathrm{~m}$ is decreasing another $2 \mathrm{~mm}$ at reference point's pile head. More stiffness added to clayshale then increases its shear strength thus when observed few depths, this research obtained lateral displacement on clayshale might decrease when additional stiffness applied.

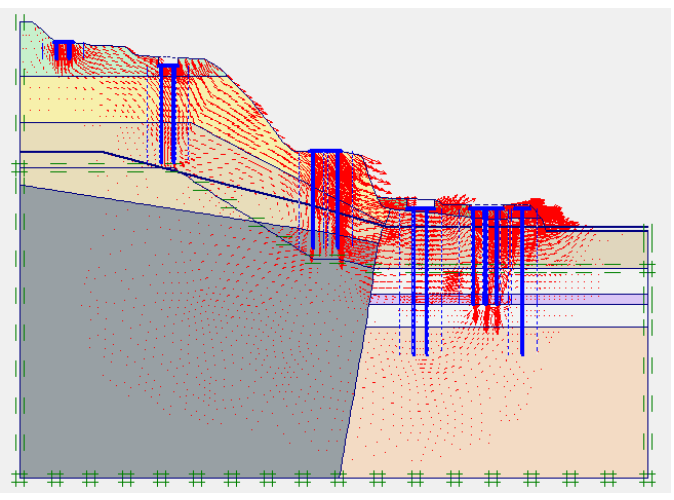

(a)

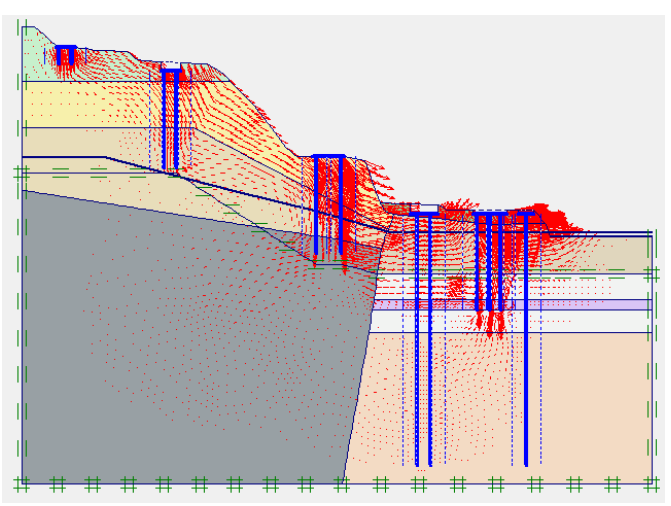

(b)

Fig. 9. Total displacement post-reinforced 1 row at right side and 2 rows at left side of pier P2 (a) $35 \mathrm{~m}$, (b) $60 \mathrm{~m}$

Critical slip surface occurs at the left side of pier P2 after this reinforcement applied. Exactly in between pier P2 and reinforcement bore pile located at its left side. This phenomenon can be seen by soil vector going up at that point at Figure 9. In general, the amount of lateral displacement itself decreased, thus slope's safety factor increases for $14,5-16 \%$ varies with reinforcement bore pile length.

\section{51 Row at right side and 3 rows at left side of pier P2}

Since the previous reinforcement is convergent with its expected value, in which decreasing lateral pile displacement with less pile length, thus this research adds another row on the left side of pier P2. This reinforcement is modelled to increase clayshale shear strength through bore pile stiffness. Figure 10 illustrate that soil vector is still dominated by lateral displacement on both models. But the amount of lateral displacement itself reach its least throughout this research for $18,41 \mathrm{~cm}$ or lessen for $68 \%$ compared to the existing displacement. Additional length from $35 \mathrm{~m}$ to $60 \mathrm{~m}$ is insignificant because it decreases 
lateral displacement for $3 \mathrm{~mm}$. Displacement pattern along reference point's pile is constant with the previous reinforcement where decreases better half-length to bottom pile.

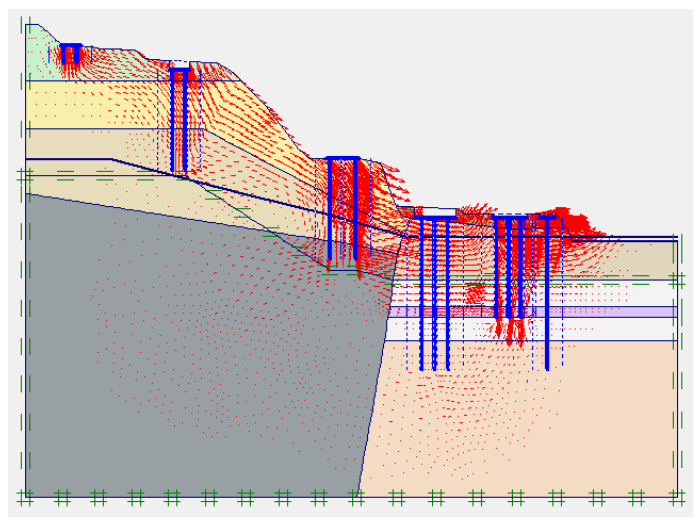

(a)

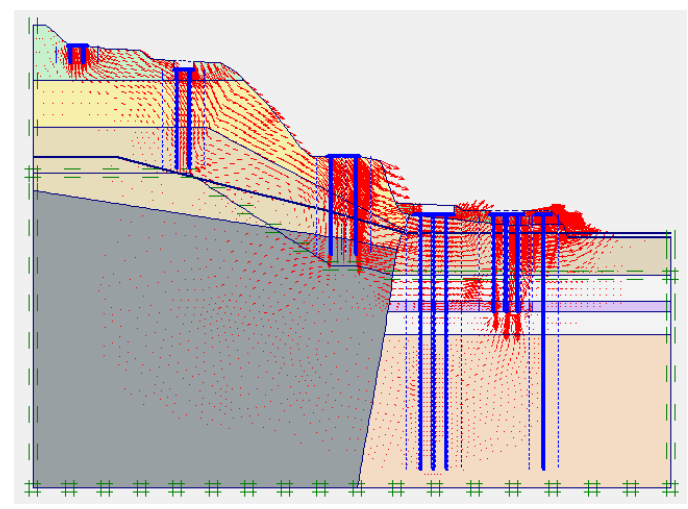

(b)

Fig. 10. Total displacement post-reinforced 1 row at right side and 3 rows at left side of pier P2 (a) $35 \mathrm{~m}$, (b) $60 \mathrm{~m}$.

Slope stability analysis obtained that safety factor after this reinforcement applied increased $13 \%$. This amount is less than the previous reinforcement because reinforcement bore pile located too close to steep slope near pier P1. Disturbed slope then causing instability due to greater displacement possibly occurs on that slope during failure. Thus, decrease safety factor value compared by the previous reinforcement. Critical slip surface is still located at the left side of pier P2.

In general, Table 3 (see Appendix) tabulated every result this research obtained. Starting with existing condition (no intervention) and continued by variation of reinforcement. Both lateral displacement and factors of safety are compared one and another. Due to soil parameter in which validated through pile cap lateral displacement from monitoring data, Table 3 in Appendix compares pile cap lateral displacement to comprehend behaviour of bore pile on clayshale.

\section{Conclusion}

In conclusion, this research presents numerical analyses conducted to determine impact of bore pile to lateral displacement and slope stability on a slope over clayshale.
This case study is analysed using PLAXIS with plastic analysis used to analyse lateral displacement and phi-c reduction to analyse slope stability. Soil stratification, especially on clayshale is classified using NSPT values. Clayshale is classified to 4 types due to its weathering process where the weathered and high weathered type has very low shear strength ranging around 5,5-10 kN/m2. Soil parameter is validated trough pile cap lateral displacement based on monitoring data on pier P1 for 26 $\mathrm{cm}$ and pier P2 for $57 \mathrm{~cm}$. Moreover, reinforcement bore pile varies in amount, length, and location in this research to comprehend its behaviour. Based on numerical results, following conclusion can be drawn:

1. Lateral displacement is affected by lateral soil movement especially on Cisomang clayshale because the soil is weathered for $30 \mathrm{~m}$ depth. This condition causing pile head to half-length of the reference point's pile (the existing pile) shifted. However, the 22-m length pile is not fail because weathered clayshale is classified as very soft soil.

2. Soil reinforcement with bore pile is effective to decrease lateral displacement of the existing pile. Bore pile increase surrounded soil strength through its flexural and axial stiffness. This phenomenon is presented as lateral displacement post-reinforced decreased for $33-68 \%$ depending on reinforcement configuration.

3. In this case study, since the critical slip surface is located at the right side of pier P2, reinforcement bore pile is more effective at decreasing pier P2's pile when located $4 \mathrm{~m}$ at the right side next to pier $\mathrm{P} 2$. To optimize bore pile behaviour in increasing soil strength, reinforcement better be done in both side of pier $\mathrm{P} 2$.

4. The least lateral displacement then obtained at slope model post-reinforced by 1 row bore pile at the right side and 3 rows bore pile at the left side of pier P2. Pile head lateral displacement is at $18 \mathrm{~cm}$ while bottom pile lateral displacement is $1 \mathrm{~cm}$. Lateral displacement at half-length to bottom pile is less than that on the pile head because the existing pile is located at weathered clayshale in which flanked by clayshale with great cohesion since it is low weathered.

5. Slope stability increased due to soil reinforcement with bore pile. Increased safety factor varies from $4.7-16 \%$. The greatest value of safety factor is obtained in slope model post-reinforced by 1 row bore pile at the right side and 2 rows bore pile at the left side of pier P2 for 1,614. That value already exceeds 1,5 which defines that slope become stable post improved.

The authors wish to gratefully acknowledge the financial support received through the Indexed International Publication Grant for Student Final Project (PITTA) No.233/UN2.R3.1/PPM.00/2018, which is funded by Universitas Indonesia. 


\section{References}

1. D.D. Putra, Studi Perilaku Model Pondasi TiangRakit Yang Mengalami Gerakan Lateral Tanah Akibat Galian Dengan Dinding Penahan Dengan Menggunakan Analisis Metode Elemen Hingga, Universitas Indonesia, Depok (2014)

2. L.D. Wesley, Geotechnical Engineering in Residual Soil ,John Wiley \& Sons. Inc, New Jersey (2010)

3. M.A. Agung, S. Pramusandi, and B. Damianto, Identification and Classification of Clayshale Characteristic and Some Consideration for Slope Stability, African Journal of Environmental Science and Technology 11, 163-197 (2017)

4. E. Hoek, Practical Rock Engineering. Evert Hoek Consulting Engineer Inc, Vancouver (2006).

5. R. Tenzer, P. Sirguey, M. Rattenbury, and J. Nicolson, A Digital Rock Density Map of New Zealand, Computers \& Geosciences 37, 1181-1191 (2011)

6. The U.S. Department of Agriculture, Geology National Engineering Handbook: Engineering Classification of Rock Materials, The U.S. Department of Agriculture, Washington (2012)

7. M. Budhu, Soil Mechanics and Foundation 3rd Ed. John Wiley \& Sons, Denver (2011)

8. R.F. Craig, Craig's Soil Mechanics ,Spon Press, London (2004).

9. G. Tjie-Liong, Common Mistakes on the Application of Plaxis $2 D$ in Analyzing Excavation Problems, International Journal of Applied Engineering Research 9, 8291-8311(2014)

10. PUSJATAN, Laporan Penelitian Kondisi Jembatan Cisomang: Ruas Jalan Tol Purbaleunyi, PUSJATAN, Bandung (2016) 


\section{Appendix}

Table 2. Soil Parameters

\begin{tabular}{|c|c|c|c|c|c|c|c|c|}
\hline Soil & $\begin{array}{c}\text { Material } \\
\text { Type }\end{array}$ & $\begin{array}{c}\boldsymbol{\gamma}_{\text {unsat }} \\
{\left[\mathrm{kN} / \mathrm{m}^{3}\right]}\end{array}$ & $\begin{array}{c}\boldsymbol{\gamma}_{\text {sat }} \\
{\left[\mathrm{kN} / \mathrm{m}^{3}\right]}\end{array}$ & $\begin{array}{c}\boldsymbol{k}_{\boldsymbol{x}}=\boldsymbol{k}_{\boldsymbol{y}} \\
{[\mathrm{m} / \mathrm{day}]}\end{array}$ & $\begin{array}{c}\boldsymbol{v} \\
{[-]}\end{array}$ & $\begin{array}{c}\boldsymbol{E}_{\boldsymbol{r e f}} \\
{\left[\mathrm{kN} / \mathrm{m}^{2}\right]}\end{array}$ & $\begin{array}{c}\boldsymbol{c} \\
{\left[\mathrm{kN} / \mathrm{m}^{2}\right]}\end{array}$ & $\begin{array}{c}\boldsymbol{\phi} \\
{\left[{ }^{0}\right]}\end{array}$ \\
\hline Breccia & Drained & 24.0 & 26.0 & 0.01 & 0.30 & 100000 & 300.0 & 47.0 \\
\hline $\begin{array}{c}\text { Clayey Sand - } \\
\text { Stiff }\end{array}$ & Drained & 21.5 & 23.0 & 0.01 & 0.30 & 74000 & 28.5 & 45.4 \\
\hline Clayey Sand & Drained & 21.0 & 23.0 & 0.01 & 0.30 & 73000 & 30.0 & 45.0 \\
\hline Silty Clay & Undrained & 18.0 & 20.0 & $10^{-6}$ & 0.33 & 25000 & 34.0 & 26.0 \\
\hline $\begin{array}{c}\text { Clayshale - } \\
\text { Not } \\
\text { Weathered }\end{array}$ & Undrained & 19.0 & 22.0 & $10^{-6}$ & 0.30 & 100000 & 250.0 & 32.0 \\
\hline $\begin{array}{c}\text { Clayshale - } \\
\text { Low } \\
\text { Weathered }\end{array}$ & Undrained & 18.5 & 22.0 & $10^{-6}$ & 0.30 & 70000 & 228.0 & 32.0 \\
\hline $\begin{array}{c}\text { Clayshale - } \\
\text { Weathered }\end{array}$ & Undrained & 17.5 & 19.5 & $10^{-6}$ & 0.30 & 55000 & 10.0 & 30.0 \\
\hline $\begin{array}{c}\text { Clayshale - } \\
\text { High } \\
\text { Weathered }\end{array}$ & Undrained & 17.0 & 19.5 & $10^{-6}$ & 0.30 & 37700 & 5.5 & 20.0 \\
\hline $\begin{array}{c}\text { Silty Clay - } \\
\text { Weathered }\end{array}$ & Undrained & 16.0 & 18.5 & $10^{-6}$ & 0.30 & 25000 & 34 & 18.0 \\
\hline
\end{tabular}

Table 3. Results Comparison

\begin{tabular}{|c|c|c|c|c|c|c|}
\hline \multirow{2}{*}{ No } & $\begin{array}{c}\text { Diameter } \\
{[\mathrm{m}]}\end{array}$ & $\begin{array}{c}\text { Length } \\
{[\mathrm{m}]}\end{array}$ & $\begin{array}{c}\text { Location } \\
\text { (from pier P2) }\end{array}$ & \multicolumn{2}{|c|}{$\begin{array}{c}\text { Pilecap Lateral } \\
\text { Displacement } \\
(\mathrm{cm})\end{array}$} & \multirow{2}{*}{ SF } \\
\cline { 5 - 7 } & & & P1 & P2 & \\
\hline \multicolumn{7}{|c|}{ Existing } \\
\hline 1 & 1 & 22 & - & 26,00 & 57,13 & 1,389 \\
\hline \multicolumn{7}{|c|}{ Reinforcement } \\
\hline 1 & 1,5 & 35 & Right & 21,84 & 22,72 & 1,455 \\
\hline 2 & 1,5 & 60 & Right & 21,45 & 22,74 & 1,468 \\
\hline 3 & 1,5 & 35 & Left & 21,82 & 38,32 & 1,464 \\
\hline 4 & 1,5 & 60 & Left & 21,79 & 38,14 & 1,486 \\
\hline 5 & 1,5 & 35 & Right \& Left & 18,77 & 20,28 & 1,529 \\
\hline 6 & 1,5 & 60 & Right \& Left & 18,51 & 20,18 & 1,554 \\
\hline 7 & 1,5 & 35 & 1 Right \& 2 Left & 17,20 & 19,53 & 1,591 \\
\hline 8 & 1,5 & 60 & 1 Right \& 2 Left & 17,18 & 19,29 & 1,614 \\
\hline 9 & 1,5 & 35 & 1 Right \& 3 Left & 16,63 & 19,01 & 1,580 \\
\hline 10 & 1,5 & 60 & 1 Right \& 3 Left & 16,35 & 18,50 & 1,581 \\
\hline
\end{tabular}

